\author{
А. А. Котвицька ${ }^{1}$, Т. Д. Криворучко ${ }^{1}$, К. С. Непорада ${ }^{1}$, С. М. Береговий \\ ПОЛТАВСЬКИЙ ДЕРЖАВНИЙ МЕДИЧНИЙ УНІВЕРСИТЕТ \\ ІНСТИТУТ БІОЛОГІЇ ТА МЕДИЦИНИ КИЇВСЬКОГО НАЦІОНАЛЬНОГО УНІВЕРСИТЕТУ \\ IMEHI TAPACA ШЕВЧEHКА², КИї̈
}

\title{
РОЗВИТОК ПАРОДОНТАЛЬНОГО СИНДРОМУ В ЩУРІВ ЗА УМОВ СТРЕПТОЗОЦИНІНДУКОВАНОЇ ДІАБЕТИЧНОЇ НЕЙРОПАТІЇ
}

Вступ. Відповідно до оцінки ВООЗ, у 2019 р. чукровий діабет став безпосередньою причиною 1,5 мільйона випадків смерті. За даними Міжнародної феедерації діабету 2011 р., кількість хворих на цукровий діабет у світі досягла рекордної цифрри - 366 мільйонів, а у 2030 р. становитиме 552 мільйони. Діабетична перифрерична нейропатія є найпоширенішим ускладненням цукрового діабету і причиною низької якості життя, порушення працездатності у великої кількості хворих. Відомо, що ускладненням цукрового діабету, який призводить до розвитку діабетичної нейропатії, є пародонтальний синдром, механізми якого ще недостатньо вивчено.

Мета дослідження - виявити патологічні зміни у тканинах пародонта щурів за умов стрептозоциніндукованої діабетичної нейропатії.

Методи дослідження. Піддослідним тваринам моделювали діабетичну нейропатію шляхом одноразового введення стрептозоцину (Streptozocin, "Sigma”, США) внутрішньочеревно з розрахунку 65 мг/кг. На 30-ту добу експерименту виконували глюкозотолерантний тест. Підтвердження розвитку діабетичної нейропатії оцінювали, вимірюючи поріг больової чутливості за допомогою тензоалгометричного тесту Randall-Selitto. У м'яких тканинах пародонта щурів визначали загальну протеолітичну активність, загальну антитриптичну активність, вміст ТБК-активних продуктів, вміст окисномодифрікованих протеїнів та активність каталази, вміст вільної фуккози і глікозаміногліканів.

Результати й обговорення. У результаті проведених досліджень встановлено, що у тварин, яким моделювали діабетичну нейропатію, поріс больової чутливості значно зростав у всі дні вимірювання порівняно з початковим значенням $((100,1 \pm 3,4) \%):$ на 14-й день після введення стрептозоцину він збільшився на $(22,4 \pm 8,4) \%(p<0,05)$, а на 28-й - на $(100,9 \pm 15,3) \%(p<0,001)$. За умов розвитку діабетичної нейропатії у тканинах пародонта щурів зростав вміст вільної фрукози та глікозаміногліканів порівняно з контрольними тваринами. Спостерігали підвищення загальної протеолітичної активності на тлі збільщення рівня інгібіторів протеїназ та інтенсифрікацію вільнорадикальних процесів з розвитком оксидативного стресу.

Висновок. Стрептозоциніндукована діабетична нейропатія призводить до розвитку пародонтального синдрому в щурів, про що свідчать активація протеолітичних процесів, розвиток оксидативного стресу, підвищення катаболізму глікопротеїнів та протеогліканів сполучної тканини пародонта.

КЛЮчОВІ СЛОВА: діабетична нейропатія; пародонт; протеїназно-інгібіторний баланс; оксидативний стрес.

ВСТУП. За даними ВООЗ, захворюваність на цукровий діабет постійно зростає і становить серед людей, старших 18 років, 8,5 \% населення планети $[1,2]$, в Україні - 9,1 \% (чоловіки 8,3 \%, жінки - 9,7 \%). "Шосте ускладнення цукрового діабету - це пародонтоз", ще на початку 1990-х років H. Löe та iн. це обґрунтували [3]. Цукровий діабет однозначно підтверджено як основний фрактор ризику захворювань тканин

(c) А. А. Котвицька, Т. Д. Криворучко, К. С. Непорада, С. М. Береговий, 2021. пародонта [4, 5], що збільшується приблизно в 3 рази у хворих на цукровий діабет порівняно 3 пацієнтами без нього [6].

Цукровий діабет призводить до розвитку мікроангіопатій та до ішемії, яку вважають центральною в патогенезі периферичної нейропатії, включаючи невралгію трійчастого нерва $[7,8]$. Ретроспективне дослідження Z. Хu та ін. обґрунтувало зв'язок між двома захворюваннями цукровим діабетом і невралгією трійчастого нерва [8]. 
Останнім часом багато уваги приділяють "двосторонньому" зв'язку між цукровим діабетом і пародонтитом [9-12]. Крім того, різні дослідження показали, що поширеність і тяжкість нестоматологічних ускладнень, пов'язаних із цукровим діабетом, у тому числі ретинопатії, діабетичної нейропатії, протеїнурії і серцево-судинних захворювань, корелюють 3 тяжкістю пародонтиту [13, 14]. Підтвердженням наявності взаємозв'язку між цукровим діабетом і станом пародонта $€$ той факт, що ефективна терапія захворювань тканин пародонта може призводити до зниження $\mathrm{HbA}_{1 \mathrm{c}}$ приблизно на 0,4 \% $[15,16]$. Попередні рандомізовані дослідження показали, що лікування пародонтиту покращувало глікемічний контроль у пацієнтів із цукровим діабетом 2 типу, таким чином знижуючи ризики розвитку мікросудинних захворювань, пов'язаних із цукровим діабетом 2 типу, та серцево-судинних захворювань. Розширення охоплення пародонтальним лікуванням пацієнтів із цукровим діабетом 2 типу і пародонтитом попередить випадання зубів на 34,1 \% та мікросудинні ускладнення, зокрема несрропатію, нейропатію і ретинопатію, відповідно, на 20,5, 17,7 та $18,4 \%$ [17].

Отже, механізми розвитку пародонтального синдрому як ускладнення цукрового діабету і діабетичної нейропатії - потужного нейротрофрічного фрактора в патогенезі захворювань тканин пародонта недостатньо вивчено.

Мета дослідження - виявити патологічні зміни у тканинах пародонта щурів за умов стрептозоциніндукованої діабетичної нейропатії.

МЕТОДИ ДОСЛІДЖЕННЯ. Дослідження виконано на 22 білих щурах масою 180-200 г. При проведенні експериментів було дотримано норматив Конвенції з біоетики Ради Європи 1997 року, Європейської конвенції про захист хребетних тварин, що використовуються для дослідних та інших наукових цілей, загальних етичних принципів експериментів на тваринах, які ухвалено на Першому національному конгресі України з біоетики.

Піддослідним тваринам моделювали діабетичну нейропатію (ДН) шляхом одноразового введення стрептозоцину (Streptozocin, "Sigma", США) внутрішньочеревно з розрахунку 65 мг/кг. Рівень глюкози визначали на 7-му, 14-ту, 21-шу та 28-му доби експерименту за допомогою глюкометра "Free Style Optium XEMV036-P0270" і тест-смужок Free Style Optium Н. Для вимірювання кров відбирали з хвостової вени, використовуючи внутрішньовенний катетер. На 30-ту добу експерименту проводили глюкозотолерантний тест. Підтвердження розвитку ДН оцінювали, вимірюючи поріг больової чутливості (ПБЧ) за допомогою тензоалгометричного тесту RandallSelitto.

Забій тварин здійснювали під тіопенталовим наркозом шляхом кровопускання, після чого проводили забір біологічного матеріалу. Об'єктами дослідження були м'які тканини пародонта щурів, у гомогенаті яких визначали загальну протеолітичну активність [18], загальну антитриптичну активність [19], вміст ТБК-активних продуктів [20], вміст окисномодифрікованих протеїнів (ОМП) [21] та активність каталази [22], вміст вільної ффукози [23] і глікозаміногліканів (ГАГ) [24].

РЕЗУЛЬТАТИ Й ОБГОВОРЕННЯ. І ЗаХВОрювання пародонта, і периферична нейропатія $\epsilon$ ускладненнями, пов'язаними з неконтрольованим цукровим діабетом. R. L. Balkaran та ін. довели, що захворювання тканин пародонта більш поширене і більш тяжке серед пацієнтів із діабетичною перифреричною нейропатією [25].

Ми встановили, що стрептозоцин викликав у щурів цукровий діабет з розвитком ДН, проявом якої було збільшення порога больової чутливості, яку вимірювали тензоалгометричним методом. У результаті проведених досліджень 3'ясовано, що в контрольних тварин початкове значення ПБЧ становило $(100,1 \pm 3,4) \%$, на 14 -й, 28-й дні вимірювання ПБЧ незначно коливався в межах початкового рівня, що свідчило про нормальне фрункціонування нервово-м'язового комплексу в щурів. У тварин, яким моделювали ДН, ПБЧ значно зростав у всі дні вимірювання порівняно з початковим значенням: на 14-й день після введення стрептозоцину - на $(22,4 \pm 8,4) \%$ $(p<0,05)$, а на 28-й - на $(100,9 \pm 15,3) \%(p<0,001)$.

За умов розвитку ДН у тканинах пародонта щурів збільшувався вміст вільної срукози (в 1,3 раза) та ГАГ (в 1,6 раза) порівняно з контролем (табл. 1). Це свідчило про те, що ДН викликала підвищений катаболізм полімерів сполучної тканини пародонта тварин.

R. Suresh та ін. обґрунтували, що рівень сіалових кислот, які належать до сімейства ацетильованих похідних нейрамінової кислоти, у сироватці крові можна розглядати як новий біомаркер у прогресуванні захворювань тканин пародонта і діабетичного статусу [26].

Аналізуючи протеїназно-інгібіторний баланс у тканинах пародонта щурів, ми встановили, що за умов розвитку ДН вірогідно зростала загальна протеолітична активність на тлі достовірного збільшення загальної антитриптичної активності порівняно з контрольними тваринами (табл. 2). Це свідчило про активацію протеолітичних процесів за умов стрептозоциніндукованої ДН у тканинах пародонта тварин. 
Таблиця 1 - Вміст вільної фукози та глікозаміногліканів у тканинах пародонта щурів за умов діабетичної нейропатії

\begin{tabular}{||l|c|c||}
\hline \multicolumn{1}{|c|}{ Група тварин } & Вміст ГАГ, мкмоль/г & Вміст фрукози, мкмоль/г \\
\hline Контроль $(\mathrm{n}=10)$ & $0,61 \pm 0,05$ & $7,93 \pm 0,19$ \\
\hline Діабетична нейропатія $(\mathrm{n}=12)$ & $0,99 \pm 0,03$ & $10,61 \pm 0,38$ \\
\hline Статистичний показник & $\mathrm{p}_{1-2}<0,05$ & $\mathrm{p}_{1-2}<0,05$ \\
\hline
\end{tabular}

Примітка. Тут і в таблицях 2, 3: n - кількість тварин.

Таблиця 2 - Протеїназно-інгібіторний баланс у тканинах пародонта щурів за умов діабетичної нейропатії

\begin{tabular}{||l|c|c||}
\hline \multicolumn{1}{|c|}{ Група тварин } & $\begin{array}{c}\text { Загальна антитриптична } \\
\text { активність, г/кг }\end{array}$ & $\begin{array}{c}\text { Загальна протеолітична } \\
\text { активність, мкг/г·хв }\end{array}$ \\
\hline Контроль $(\mathrm{n}=10)$ & $32,56 \pm 1,31$ & $3,17 \pm 0,01$ \\
\hline Діабетична нейропатія $(\mathrm{n}=12)$ & $53,85 \pm 0,71$ & $3,41 \pm 0,03$ \\
\hline Статистичний показник & $\mathrm{p}_{1-2}<0,05$ & $\mathrm{p}_{1-2}<0,05$ \\
\hline \hline
\end{tabular}

Протеолітичні ензими беруть активну участь у запаленні й ремоделюванні тканин, що супроводжуються різними нейродегенеративними захворюваннями, включаючи дП.

Одним із провідних фракторів у розвитку різних патологічних станів $€$ порушення окиснювально-антиоксидантної рівноваги, що реалізує розвиток оксидативного стресу. Тому показники вільнорадикальних процесів і стан антиоксидантної системи можуть бути використані як маркери оцінки ступеня ушкодження клітин. У наших дослідженнях інтенсивність вільнорадикальних процесів у гомогенаті тканин пародонта оцінювали за вмістом вторинних продуктів пероксидного окиснення ліпідів - ТБК-активних реактантів, а також за вмістом продуктів ОМП та активністю каталази.

За умов ДН на 30-й день експерименту спостерігали розвиток оксидативного стресу в тканинах пародонта тварин, про що свідчило достовірне зростання вмісту ТБК-активних продуктів та ОМП (табл. 3). Згідно з отриманими даними, в щурів з ДН порушувалася рівновага в про/ антиоксидантній системі в бік активації процесів вільнорадикального окиснення на тлі зниження антирадикальних механізмів захисту, що призводило до вивільнення продуктів ліпопероксидації та розвитку ендогенної інтоксикації.

Карбонільний стрес, інтегральним показником якого $є$ вміст ОМП, розглядають як один 3 можливих фракторів інактивації ензимів і зміни структурної організації протеїнів у стані оксидативного стресу. В наших дослідженнях активність каталази в тканинах пародонта щурів 3 ДН вірогідно зменшилась порівняно з контрольними тваринами (див. табл. 3). Отже, ми можемо стверджувати, що за умов розвитку ДН відбувається надмірна ініціація синтезу активних фрорм кисню у тканинах пародонта щурів, що призводить до зменшення потужності антиоксидатного захисту, результатом чого і $є$ розвиток оксидативного стресу.

Збільшення рівня активних фрорм кисню призводить до активації NF-kB, який відіграє важливу роль у патогенезі ускладнень цукрового діабету. Активація NF-kB викликає експресію різних прозапальних цитокінів, індуцибельної синтази оксиду азоту, активацію циклооксигенази-2 та інше, що, у свою чергу, сприяє подальшій альтерації тканин.

Таблиця 3 - Показники оксидативного стресу в тканинах пародонта щурів за умов діабетичної нейропатії

\begin{tabular}{||l|c|c|c|c||}
\hline \multicolumn{1}{|c|}{ Група тварин } & $\begin{array}{c}\text { Активність } \\
\text { каталази, } \\
\text { мккат/г·хв }\end{array}$ & $\begin{array}{c}\text { Вміст ОМП, } \\
\text { ум. од. }\end{array}$ & $\begin{array}{c}\text { Вмкіст } \\
\text { тБреактантів, } \\
\text { мкмоль/г }\end{array}$ & $\begin{array}{c}\text { Вміст молекул } \\
\text { середьої маси, } \\
\text { ум. од. }\end{array}$ \\
\hline Контроль $(\mathrm{n}=10)$ & $0,27 \pm 0,04$ & $1,35 \pm 0,01$ & $2,41 \pm 0,13$ & $0,29 \pm 0,02$ \\
\hline Діабетична нейропатія $(\mathrm{n}=12)$ & $0,11 \pm 0,01$ & $1,76 \pm 0,03$ & $4,45 \pm 0,03$ & $0,33 \pm 0,01$ \\
\hline Статистичний показник & $\mathrm{p}_{1-2}<0,05$ & $\mathrm{p}_{1-2}<0,05$ & $\mathrm{p}_{1-2}<0,05$ & $\mathrm{p}_{1-2}<0,05$ \\
\hline \hline
\end{tabular}

ВИСНОВОК. Стрептозоциніндукована діабетична нейропатія призводить до розвитку патологічних змін у тканинах пародонта щурів, про що свідчать активація протеолітичних процесів та розвиток оксидативного стресу, що сприяє підвищеному катаболізму неколагенових полімерів сполучної тканини.

Перспективи подальших досліджень - на підставі дослідження механізмів розвитку ушкодження тканин пародонта за умов стрептозоцин- 
індукованої діабетичної нейропатії обґрунтувати експериментальну корекцію патологічних змін пародонта за допомогою препарату метаболічної дії "Кокарніт".

\section{СПИСОК ЛІТЕРАТУРИ}

1. Diabetes. Informational letter Nov 2016. (In Russian). -Access mode : http://www.who.int/mediacentre/factsheets/fs312/ru/.

2. Global report on diabetes mellitus. (In Russian). Access mode: http://apps.who.int/iris/bitstream/10665/ 204874/4/WHO_NMH_NVI_16.3_rus.pdf?ua=1.

3. Löe H. Periodontal disease. The sixth complication of diabetes mellitus / H. Löe // Diabetes Care. - 1993. 16, No. 1. - P. 329-334.

4. Salvi G. E. Effects of diabetes mellitus on periodontal and peri-implant conditions: update on associations and risks [Electronic resource] / Giovanni E. Salvi, Barbara Carollo-Bittel, Niklaus P. Lang // Journal of Clinical Periodontology. - 2008. - 35. - P. 398-409. Access mode : https://doi.org/10.1111/j.1600-051x. 2008.01282.x

5. Periodontal status of diabetics compared with nondiabetics: a meta-analysis [Electronic resource] / Yousef S. Khader, A. S. Dauod, S. S. El-Qaderi [et al.] // Journal of Diabetes and its Complications. - 2006. - 20 No. 1. - P. 59-68. - Access mode : https://doi.org/10. 1016/j.jdiacomp.2005.05.006

6. Mealey B. L. Diabetes mellitus and periodontal disease [Electronic resource] / Brian L. Mealey, Gloria L. Ocampo // Periodontology 2000. - 2007. - 44, No. 1. P. 127-153. - Access mode : https://doi.org/10.1111/j. 1600-0757.2006.00193.x

7. Gordon Smith A. Idiopathic neuropathy, prediabetes and the metabolic syndrome [Electronic resource]/ A. Gordon Smith, J. Robinson Singleton // Journal of the Neurological Sciences. -2006. -242, No. 1-2. - P. 9-14. Access mode : https://doi.org/10.1016/j.jns.2005.11.020

8. Diabetes mellitus in classical trigeminal neuralgia: A predisposing factor for its development [Electronic resource] / Z. Xu, P. Zhang, L. Long [et al.] // Clinical Neurology and Neurosurgery. - 2016. - 151. - P. 70-72. Access mode : https://doi.org/10.1016/j.clineuro.2016. 10.015

9. Taylor G. W. Bidirectional interrelationships between diabetes and periodontal diseases: An epidemiologic perspective [Electronic resource] / G. W. Taylor // Annals of Periodontology. - 2001. - 6, No. 1. - P. 99112. - Access mode : https://doi.org/10.1902/annals. 2001.6.1.99

10. "Diabetes and gum disease: The diabolic duo" [Electronic resource] / Manoj Kumar, L. Mishra, R. Mohanty [et al.] // Diabetes \& Metabolic Syndrome: Clinical Research \& Reviews. - 2014. - 8, No. 4. - P. 255-258. Access mode : https://doi.org/10.1016/j.dsx.2014.09.022

11. The relationship between oral health and diabetes mellitus [Electronic resource] / Ira B. Lamster, E. Lalla, W. S. Borgnakke [et al.] // The Journal of the American Dental Association. - 2008. - 139. - P. 19S-24S. -Access mode : https://doi.org/10.14219/jada.archive.2008.0363

12. Lamster I. B. Non-periodontal oral complications of diabetes mellitus [Electronic resource] / Ira B. Lamster // Diabetes Mellitus and Oral Health. - Hoboken, NJ, USA,
2014. - P. 157-190. - Access mode : https://doi. org/10.1002/9781118887837.ch8

13. Diabetes as a risk factor for periodontal diseaseplausible mechanisms [Electronic resource] / D. Polak, T. Sanui, F. Nishimura, L. Shapira // Periodontology 2000. - 2020. - 83, No. 1. - P. 46-58. - Access mode: https://doi.org/10.1111/prd.12298

14. Stanko P. Bidirectional association between diabetes mellitus and inflammatory periodontal disease. A review [Electronic resource] / Peter Stanko, Lydie Izakovicova Holla // Biomedical Papers. - 2014. - 158, No. 1. P. 035-038. - Access mode : https://doi.org/10.5507/ bp.2014.005

15. Treatment of periodontal disease for glycaemic control in people with diabetes [Electronic resource] / T. C. Simpson, J. C. Weldon, H. V. Worthington [et al.] // Australian Dental Journal. - 2010. - 55, No. 4. - P. 472474. - Access mode : https://doi.org/10.1111/j.18347819.2010.01273.x

16. Liu W. Effect of periodontal therapy on glycemic control in diabetic patients: A systematic review and network meta-analysis [Electronic resource]: Thesis / W. Liu. - 2017. - Access mode : http://hdl.handle. net/10393/35716

17. Choi S. E. Impact of treating oral disease on preventing vascular diseases: A model-based cost-effectiveness analysis of periodontal treatment among patients with type 2 diabetes [Electronic resource] / Sung Eun Choi, Corneliu Sima, Ankur Pandya // Diabetes Care. 2019. - 43, No. 3. - P. 563-571. -Access mode : https:// doi.org/10.2337/dc19-1201

18. Уголев А. М. Исследование пищеварительного аппарата у человека / А. М. Уголев, Н. Н. Иезуитова, У. Г. Масевич. - Л. : Наука, 1969. - 216 с.

19. Веремеенко К. Н. Протеолиз в норме и при патологии / К. Н. Веремеенко, О. П. Голобородько, А. И. Кизим. - К . : Здоров'я, 1988. - 200 с.

20. Стальная И. Д. Метод определения малонового диальдегида с помощью тиобарбитуровой кислоты / И. Д. Стальная, Т. Г. Гаришвили // Современные методы в биохимии. - М. : Медицина, 1977. - С. 66-68.

21. Дубинина Е. Е. Окислительная модифрикация белков сыворотки крови человека. Метод ее определения / Е. Е. Дубинина, С. О. Бурмистров // Вопросы мед. химии. -1995. - № 1. - С. 24-26.

22. Королюк М. А. Метод определения активности каталазы / М. А. Королюк, Л. И. Иванова, И. Г. Майорова // Лаб. дело. - 1988. - № 1. - С. 16-19.

23. Метод определения фрукозы, несвязанной с белками / П. Н. Шараев, Н. С. Стрелков, Р. Р. Кильдиярова [и др.] // Клинич. лаб. диагностика. - 1997. № 4. - С. 17-18.

24. Шараев П. Н. Метод определения гликозаминогликанов в биологических жидкостях / П. Н. Шараев // Лаб. дело. - 1987. - № 5. - С. 530-532.

25. The use of the slipping slipper sign to explore the connection between the feet and the mouth in patients 
with diabetes mellitus / R. L. Balkaran, S. S. Teelucksingh, R. S. Naidu [et al.] // P R Health Sci. J. - 2020. - 39 (2). P. 216-221. PMID: 32663921.

26. Effect of non-surgical periodontal therapy on the serum sialic acid levels in diabetic patients with periodon- titis [Electronic resource] / R. Suresh, P. Jayachandran, A. Fenol [et al.] // Acta Medica (Hradec Kralove, Czech Republic). - 2019. - 62, No. 3. - P. 109-116. - Access mode : https://doi.org/10.14712/18059694.2019.134

\section{REFERENCES}

1. (2016). Diabetes. Informational letter. Retrieved from: http://www.who.int/mediacentre/factsheets/ fs312/ru/.

2. Global report on diabetes mellitus. Retrieved from: http://apps.who.int/iris/bitstream/10665/204874/4/ WHO_NMH_NVI_16.3_rus.pdf?ua=1.

3. Löe, H. (1993). Periodontal disease. The sixth complication of diabetes mellitus. Diabetes Care, 16 (1), 329-334.

4. Salvi, G.E., Carollo-Bittel, B., \& Lang, N.P. (2008). Effects of diabetes mellitus on periodontal and peri-implant conditions: update on associations and risks. Journal of Clinical Periodontology, 35 (Suppl. 8), 398-409. Retrieved from: https://doi.org/10.1111/j.1600-051X. 2008.01282.x

5. Khader, Y.S., Dauod, A.S., El-Qaderi, S.S., Alkafajei, A., \& Batayha, W.Q. (2006). Periodontal status of diabetics compared with nondiabetics: a meta-analysis. Journal of Diabetes and its Complications, 20 (1), 59-68. Retrieved from: https://doi.org/10.1016/j.jdiacomp. 2005.05.006

6. Mealey, B.L., \& Ocampo, G.L. (2007). Diabetes mellitus and periodontal disease. Periodontology 2000, 44, 127-153. Retrieved from: https://doi.org/10.1111/ j.1600-0757.2006.00193.x

7. Gordon Smith, A., \& Robinson Singleton, J. (2006). Idiopathic neuropathy, prediabetes and the metabolic syndrome. Journal of the Neurological Sciences, 242 (1-2), 9-14. Retrieved from: https://doi.org/10.1016/j. jns.2005.11.020

8. Xu, Z., Zhang, P., Long, L., He, H., Zhang, J., \& Sun, S. (2016). Diabetes mellitus in classical trigeminal neuralgia: A predisposing factor for its development. Clinical Neurology and Neurosurgery, 151, 70-72. Retrieved from: https://doi.org/10.1016/j.clineuro. 2016.10.015

9. Taylor, G.W. (2001). Bidirectional interrelationships between diabetes and periodontal diseases: an epidemiologic perspective. Annals of Periodontology, 6 (1), 99-112. Retrieved from: https://doi.org/10.1902/annals.2001.6.1.99

10. Kumar, M., Mishra, L., Mohanty, R., \& Nayak, R. (2014). "Diabetes and gum disease: the diabolic duo". Diabetes \& Metabolic Syndrome, 8 (4), 255-258. Retrieved from: https://doi.org/10.1016/j.dsx.2014.09.022

11. Lamster, I.B., Lalla, E., Borgnakke, W.S., \& Taylor, G.W. (2008). The relationship between oral health and diabetes mellitus. Journal of the American Dental Association, (1939), 139 19S-24S. Retrieved from: https:// doi.org/10.14219/jada.archive.2008.0363
12. Lamster, I.B. (2014). Non-periodontal oral complications of diabetes mellitus. Diabetes Mellitus and Oral Health, 157-190. John Wiley \& Sons, Inc. Retrieved from: https://doi.org/10.1002/9781118887837.ch8

13. Polak, D., Sanui, T., Nishimura, F., \& Shapira, L. (2020). Diabetes as a risk factor for periodontal diseaseplausible mechanisms. Periodontology 2000, 83 (1), 46-58. Retrieved from: https://doi.org/10.1111/prd.12298

14. Stanko, P., \& Izakovicova Holla, L. (2014). Bidirectional association between diabetes mellitus and inflammatory periodontal disease. A review. Biomedical papers of the Medical Faculty of the University Palacky, Olomouc, Czechoslovakia, 158 (1), 35-38. Retrieved from: https://doi.org/10.5507/bp.2014.005

15. Simpson, T.C., Weldon, J.C., Worthington, H.V., Needleman, I., Wild, S. H., Moles, D.R., Stevenson, B., Furness, S., \& Iheozor-Ejiofor, Z. (2015). Treatment of periodontal disease for glycaemic control in people with diabetes mellitus. The Cochrane Database of Systematic Reviews, 2015 (11), CD004714. Retrieved from: https:// doi.org/10.1002/14651858.CD004714.pub3

16. Teeuw, W.J., Gerdes, V.E., \& Loos, B.G. (2010). Effect of periodontal treatment on glycemic control of diabetic patients: a systematic review and meta-analysis. Diabetes Care, 33 (2), 421-427. Retrieved from: https:// doi.org/10.2337/dc09-1378

17. Choi, S.E., Sima, C., \& Pandya, A. (2020). Impact of treating oral disease on preventing vascular diseases: A model-based cost-effectiveness analysis of periodontal treatment among patients with type 2 diabetes. Diabetes Care, 43 (3), 563-571. Retrieved from: https://doi. org/10.2337/dc19-1201

18. Ugolev, A.M., lezuitova, N.N., \& Masevich, U.G. (1969). Issledovanie pishhevaritelnogo apparata u cheloveka [Study of the digestive system in humans]. Lviv: Nauka [in Ukrainian].

19. Veremeenko, K.N., Goloborodko, O.P., \& Kizim, A.I. (1988). Proteoliz v norme i pri patologii [Proteolysis in normal and pathological conditions]. Kyiv: Zdorovia [in Ukrainian].

20. Stalnaia I.D., \& Garishvili T.G. (1977). Metod opredeleniya malonovogo dialdegida s pomoshchiu tiobarbiturovoi kisloty [Method for the determination of malonic dialdehyde using thiobarbituric acid]. Sovremennye metody v biohimii - Modern Methods in Biochemistry. Moscov: Meditsina [in Russian].

21. Dubinina, E.E., \& Burmistrov, S.O. (1995) Okislitelnaya modifikatsiya belkov syvorotki krovi cheloveka. Metod ee opredeleniya [Oxidative modification of human serum proteins. Method for its determination]. Voprosy 
meditsinskoy himii - Medicinal Chemistry Issues, 1, 2426 [in Russian].

22. Koroliuk, M.A., Ivanova, L.I., \& Maiorova, I.G. (1988). Metod opredeleniya aktivnosti katalazy [Method for determination of catalase activity], Laboratornoe delo - Laboratory Work, 1, 16-19 [in Russian].

23. Sharaev, P.N, Strelkov, N.S., \& Kildiiarova, R.R. (1997). Metod opredeleniya fukozy, nesviazannoy s belkami [Method for determination of fucose unbound to proteins] Klinicheskaya laboratornaya diagnostika Clinical Laboratory Diagnostics, 4, 17-18 [in Ukrainian].

24. Sharaev, P.N. (1987). Metod opredeleniya glikozaminoglikanov v biologicheskih zhidkostyah [Method for the determination of glycosaminoglycans in biological fluids]. Laboratornoe delo - Laboratory Work, 5, 530-532 [in Ukrainian].

25. Balkaran, R.L., Teelucksingh, S.S., Naidu, R.S., Lutchmansingh, K.E., Morris, L.A., Tripathi, V., \& Teelucksingh, S. (2020). The use of the slipping slipper sign to explore the connection between the feet and the mouth in patients with diabetes mellitus. Puerto Rico Health Sciences Journal, 39 (2), 216-221.

26. Suresh, R., Jayachandran, P., Fenol, A., Biswas, R., Krishnan, S., Kumar, K. A., Divakar, D.D., \& Vellappally, S. (2019). Effect of non-surgical periodontal therapy on the serum sialic acid levels in diabetic patients with periodontitis. Acta Medica (Hradec Kralove), 62 (3), 109-116. Retrieved from: https://doi.org/10.14712/ 18059694.2019.134

\section{DEVELOPMENT OF PERIODONTAL SYNDROME IN RATS UNDER STREPTOZOCIN-INDUCED DIABETIC NEUROPATHY}

\section{Summary}

Introduction. According to WHO estimates, in 2019, diabetes was the direct cause of 1.5 million deaths. According to the International Diabetes Federation, in 2011 the number of diabetics in the world reached a record figure - 366 million, and in 2030 will be 552 million. Diabetic peripheral polyneuropathy is the most common complication of diabetes and the cause of low quality of life, disability in a large number of patients. It is known that a complication of diabetes mellitus, which leads to the development of diabetic polyneuropathy is periodontal syndrome, the mechanisms of which are insufficiently studied.

The aim of the study - to detect the pathological changes in the periodontal tissues of rats under conditions of streptozocin-induced diabetic neuropathy.

Research Methods. Diabetic neuropathy by a single intraperitoneal injection of streptozocin (Streptozocin Sigma, USA) at a dose of $65 \mathrm{mg} / \mathrm{kg}$ was simulated in experimental animals. On day 30 of the experiment, a glucose tolerance test was performed. Confirmation of the development of diabetic neuropathy was evaluated by measuring the threshold of pain sensitivity using tenzoalgometric Randall-Selitto test. Total proteolytic activity, total antitryptic activity, content of TBA-active products, content of oxidatively modified proteins and catalase activity, content of free fucose and glycosaminoglycans were determined in periodontal soft tissues of rats.

Results and Discussion. As a result of studies, it was found that rats in which diabetic neuropathy was stimulated pain threshold increased significantly on all days of measurement compared with the control rats (100.1 \pm 3.4$) \%$ : on day 14 after streptozocin administration, the pain threshold increased by $(22.4 \pm 8.4) \%(p<0.05)$, and on day $28-$ by $(100.9 \pm 15.3) \%(p<0.001)$. With the development of diabetic neuropathy in the periodontal tissues of rats, the content of free fucose and glycosaminoglycans increases compared to control animals. Activation of the general proteolytic activity against increases of proteinase inhibitors and activation of free radical processes with development of oxidative stress was observed.

Conclusions. Streptozocin-induced diabetic neuropathy leads to the development of periodontal syndrome in rats, as evidenced by the activation of proteolytic processes, the development of oxidative stress, increased catabolism of non-collagenous polymers of periodontal connective tissue.

KEY WORDS: diabetic neuropathy; periodontium; proteinase-inhibitory balance; oxidative stress. 